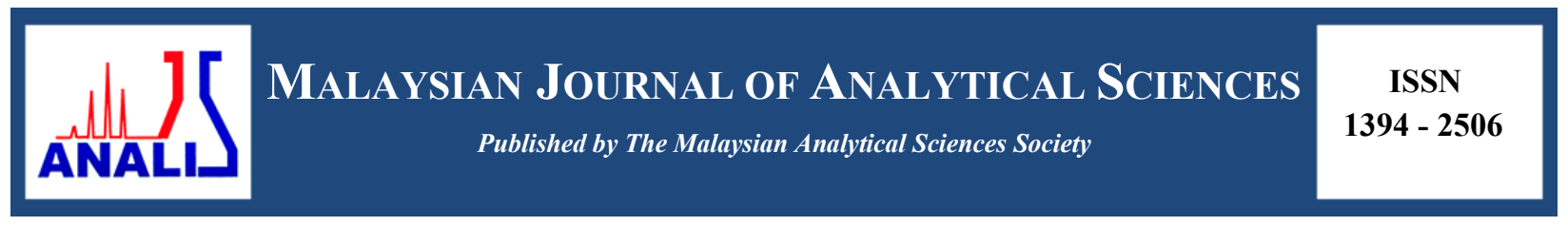

\title{
SYNTHESIS, CHARACTERIZATION AND ANTIMICROBIAL PROPERTIES OF COPPER(II) COMPLEX OF HETEROCYCLIC LIGANDS
}

\author{
(Sintesis, Pencirian dan Ciri Antimikrob Kuprum(II) Kompleks dengan Ligan Heterosiklik) \\ Rabuyah Ni*, Mohammad Isa Mohamadin, Vivien Jong Yi Mian \\ Faculty of Applied Sciences, \\ Universiti Teknologi MARA, Kampus Samarahan 2, 94300 Kota Samarahan, Sarawak, Malaysia \\ *Corresponding author: abuyani2201@gmail.com
}

Received: 21 August 2016; Accepted: 27 July 2017

\begin{abstract}
Copper(II)- $\beta$-mangostin complex was prepared by 2:1 molar reaction of ligand, $\beta$-mangostin and copper(II) acetate in one-pot reaction. The resulting complex, $\left[\mathrm{CuL}_{2}\left(\mathrm{H}_{2} \mathrm{O}\right)_{2}\right]$ has been characterized by using spectroscopic techniques. Ligand and its metal complex were tested against Escherichia coli, Pseudomonas aeruginosa, Proteus vulgaris, Klebsiella pneumonia and Salmonella pneumoniae bacteria to assess on their antibacterial properties using Minimum Inhibitory Concentrations (MICs) and Minimum Bactericidal Concentrations (MBCs) method. The UV-Vis result showed that the complex has an octahedral geometry. The general formula $\left[\mathrm{ML}_{2}\left(\mathrm{H}_{2} \mathrm{O}\right)_{2}\right]$, in which $\mathrm{L}=\beta$-mangostin, is determined from UV-Vis, FTIR and CHNS data. Ligands were completely inactive against bacteria whereas the copper(II) $\beta$-mangostin complex has significant action on bacteria, indicating that it has a good potential as bactericide.
\end{abstract}

Keywords: $\beta$-mangostin, copper(II) complex, antimicrobial, xanthones

Abstrak

Kompleks kuprum(II)- $\beta$-mangostin disediakan dengan nisbah 2:1 mol antara ligand, $\beta$-mangostin dan kuprum asetat dalam tindak balas satu-bekas. Kompleks yang dihasilkan, $\left[\mathrm{CuL}_{2}\left(\mathrm{H}_{2} \mathrm{O}\right)_{2}\right]$ dicirikan dengan menggunakan teknik spektroskopik. Ligan dan logam kompleks diuji ke atas bakteria Escherichia coli, Pseudomonas aeruginosa, Proteus vulgaris, Klebsiella pneumonia and Salmonella pneumoniae untuk menilai tindak balas bakteria menggunakan kaedah Kepekatan Perencatan Minimum (KPM) dan kaedah Kepekatan Bakteria Minimum (KBM). Keputusan UV-Vis menunjukkan kompleks mempunyai geometri oktahedron. Formula umum $\left[\mathrm{ML}_{2}\left(\mathrm{H}_{2} \mathrm{O}\right)_{2}\right]$, yang mana $\mathrm{L}=\beta$-mangostin ditentukan dari data UV-Vis, FTIR dan CHNS. Ligand sepenuhnya tidak aktif ke atas bakteria, manakala komplex kuprum(II) $\beta$-mangostin memberikan tindak balas yang signifikan ke atas bakteria, menunjukkan ia mempunyai potensi yang baik sebagai bactericide.

Kata kunci: $\beta$-mangostin, kuprum(II) kompleks, antimikrob, xanthones

\section{Introduction}

Transition metal ions such as copper(II), iron(II), iron(III) and zinc(II) have been known for many years to exert wide biological activity, for example against tumor cells [1]. Also chromones, flavonoid and coumarins have been known for similar properties. These two facts have attracted the attention of researchers to check whether metal complexes are more effective against anticancer and antibacterial than free ligands. 
Copper is an essential trace mineral present in all body tissues. Copper works with iron to help the body to form red blood cells and increase the iron absorption. It also helps to keep the blood vessels, nerves, immune system and bones healthy. Copper has a major role in the production of the very reactive hydroxyl radical through the Fenton and Haber-Weiss reaction. Copper(II) can binds and manifests large hyperchromic and bathochromic shifts in the molecular absorption spectra [2].

Another class of less explored naturally occurring ligands are xanthones. These bioactive compounds are heterotricyclic compounds originally isolated as secondary metabolites from plants and microorganisms. Previous phytochemical studies on Garcinia mangostana have resulted in isolation of more than 50 xanthones. The major components in Garcinia mangostana are xanthones, such as $\alpha$-mangostin, $\beta$-mangostin, and $\gamma$-mangostin [3]. The xanthone derivatives has a remarkable effect on antiulcerogenic, antifungal activity, antibacterial activity, inhibitors of proteinkinase, anticancer activity, antioxidant and anti-inflammatory [4], which depend on their wide range of structures modified by substituents on the ring [5].

Simultaneously, synthetic and medicinal chemistry studies of xanthones derivative have been performed [6]. In contrast, there are only a few reports that deal with complexation of metal ions with xanthones derivatives. So far, complexation having xanthones as a ligand only involve synthetic xanthones. The synthetic xanthone was prepared via reaction dihydroxyxanthone with crown ether [7] or piperidinyl [8], respectively. The macrostructure of crown ether helps to stabilize the $\mathrm{Cu}$ (II) complexes formed whereas piperidinyl structure contributed basicity properties to encourage formation of $\mathrm{Cu}(\mathrm{II})$ and $\mathrm{Zn}$ (II) complexes with simple oxygenated xanthones.

In this work, the isolated $\beta$-mangostin from Garcinia mangostana will be used as a ligand to synthesize a new metal complex having copper(II) as the central metal. The newly synthesized compound will be tested for antimicrobial properties. Isolated $\beta$-mangostin was inactive against antimicrobial [9] and anticancer [10]. The inclusion of copper(II) could alter the overall structure of newly formed synthesized compound and thus can increase the biological properties of the compound.

\section{Materials}

\section{Materials and Methods}

All the chemicals used were Analar grade. Copper(II) acetate and ethanol were used as received.

\section{Extraction, Isolation and Purification of $\beta$-mangostin}

Around 5-6 kg barks samples of Garcinia mangostana were obtained from Sarawak. $2.3 \mathrm{~kg}$ of powdered air-dried stem barks samples from Garcinia mangostana was macerated with chloroform for 48 hours at room temperature. The solvent was removed under reduced pressure using a rotavapor. The crude chloroform extract was isolated using Liquid Vacuum Chromatography and afforded 27 fractions. Same $\mathrm{R}_{\mathrm{f}}$ values on the TLC plates of $\beta$-mangostin were combined. The purity of $\beta$-mangostin was determined using Agilent HPLC Series 1260 Infinity.

\section{Synthesis of $\mathrm{Cu}(\mathrm{II})$ complexes}

The procedure to obtain metal complex was adopted from established method by Bukhari et al. [11]. $0.589 \mathrm{mmol}$ of copper(II) acetate was dissolved in ethanol. Then, $0.1178 \mathrm{mmol}$ of $\beta$-mangostin was added and the colour of the solution was olive green. The mixture was refluxed for 3 hours. After refluxed, the mixture solution was filtered and washed with ethanol for few times. The filtrate was evaporated at room temperature. The resulting complex has been characterized using UV-VIS, Fourier Transformation Infrared (FTIR) and CHNS.

\section{Instrumentations}

Ligand, $\beta$-mangostin and its metal complex were determined using Gas Chromatography - Mass Spectrometry (GCMS), Nuclear Magnetic Resonance (NMR), UV-Visible, Fourier Transformation Infrared (FTIR), High Performance Liquid Chromatography (HPLC) and CHNS analyser.

Elemental analyses (C, H and $\mathrm{N}$ ) was performed on elemental analyser Model vario MICRO cube. Infrared spectra of $\beta$-mangostin and its metal complex were recorded on a Perkin-Elmer Frontier FTIR using KBr pellet in the 
spectral range of $4000-400 \mathrm{~cm}^{-1}$. Electronic spectra of the ligands and its metal complexes will be carried out by using Perkin-Elmer Model Lambda 25.

${ }^{1} \mathrm{H}$ and ${ }^{13} \mathrm{C}$ NMR measurements were obtained on Bruker at $400 \mathrm{MHz}$, a $5 \mathrm{~mm}$ probe head in acetone- $\mathrm{d}_{6}$ at room temperature. HPLC analysis for $\beta$-mangostin was carried out on Agilent G1316A (150 mm x $4.6 \mathrm{~mm}, 5 \mu \mathrm{m})$ column, the mobile phase was $(80: 20, \mathrm{v} / \mathrm{v})$ acetonitrile/water mixture at room temperature with $1 \mathrm{~mL} \mathrm{~min}{ }^{-1}$ flow rate and a $5 \mu \mathrm{l}$ injection loop. Detection was performed with a UV detector in HPLC at $320 \mathrm{~nm}$. The xanthone scaffold having good absorption at this wavelength and only a few number of other compounds absorb making $320 \mathrm{~nm}$ wavelength for xanthone detection [12].

\section{Antimicrobial activities}

Antibacterial test for ligand and synthesized compound were carried out using Minimum Inhibitory Concentrations (MICs) and Minimum Bactericidal Concentrations (MBCs) method. The following bacteria were used as test organisms: Escherichia coli, Pseudomonas aeruginosa, Proteus vulgaris, Klebsiella pneumonia and Salmonella pneumoniae.

\section{Structural elucidation of $\beta$-mangostin}

\section{Results and Discussion}

Fraction 11 until 13 from previous vacuum column chromatography were fractionated using gravity column chromatography yielded $\beta$-mangostin. Recrystallization from chloroform yielded yellow needle crystals with melting point of $174-175{ }^{\circ} \mathrm{C}$ (Lit. $175-176{ }^{\circ} \mathrm{C}$ [13]). The $R_{f}$ value was 0.575 using a solvent system of chloroform. The molecular ion peak was found at $\mathrm{m} / \mathrm{z} 424$ indicating a molecular formula of $\mathrm{C}_{25} \mathrm{H}_{28} \mathrm{O}_{6}$. Figure 1 showed the structure of $\beta$-mangostin. The UV-Visible spectrum exhibited characteristic absorption bands of xanthone at $\lambda_{\max }$ (ethanol) 244, 259, 315 and $355 \mathrm{~nm}$. The IR spectrum showed the presence of hydroxyl group at $3399 \mathrm{~cm}^{-1}$ and a chelated carbonyl group at $1648 \mathrm{~cm}^{-1}$. The absorption band situated at $1600,1571,1458$ and 1278 $\mathrm{cm}^{-1}$ are related to carbon vibration in benzene rings. The purity of isolated $\beta$-mangostin was $98 \%$ determined from HPLC analysis.

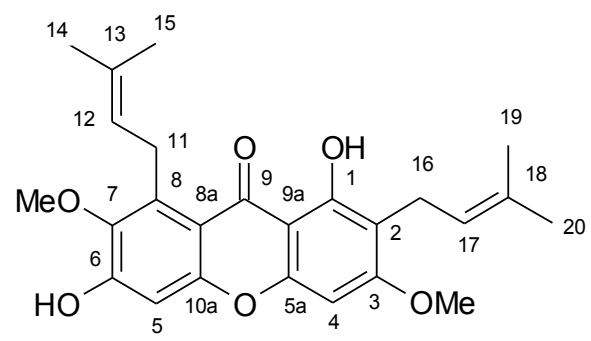

Figure 1. $\beta$-mangostin

${ }^{1} \mathrm{H}-\mathrm{NMR}$ and ${ }^{13} \mathrm{C}-\mathrm{NMR}$ data were compared with reported data by Shen et al. [15]; Al-Massarani et al. [16] and Syam et al. [17]. The ${ }^{1} \mathrm{H}$ NMR spectrum showed the presence of one chelated hydroxyl group at $\delta$ 13.66. In addition, typical signals of four allylic methyl groups at $\delta_{\mathrm{H}} 1.67(3 \mathrm{H}, \mathrm{s}, \mathrm{H}-14), 1.84(3 \mathrm{H}, \mathrm{s}, \mathrm{H}-15), 1.65(3 \mathrm{H}, \mathrm{s}, \mathrm{H}-19)$ and 1.79 $(3 \mathrm{H}, \mathrm{s}, \mathrm{H}-20)$; two pairs of methylene proton at $\delta_{\mathrm{H}} 4.15(2 \mathrm{H}, \mathrm{d}, J=6.6 \mathrm{~Hz}, \mathrm{H}-11)$ and $3.34(2 \mathrm{H}, \mathrm{d}, J=7.2 \mathrm{~Hz}, \mathrm{H}-16)$; and two olefinic protons at $5.22(2 \mathrm{H}, \mathrm{t}, J=7.3 \mathrm{~Hz}, \mathrm{H}-12)$ and $5.29(2 \mathrm{H}, \mathrm{t}, J=6.7 \mathrm{~Hz}, \mathrm{H}-17)$ were observed in the ${ }^{1} \mathrm{H}$ NMR spectrum.

The ${ }^{13} \mathrm{C}$ NMR spectrum gave a total of twenty five carbons which was validated for the molecular formula, $\mathrm{C}_{25} \mathrm{H}_{28} \mathrm{O}_{6}$. A signal at $\delta_{\mathrm{C}} 182.0$ indicated a carbonyl group in the middle ring. Meanwhile, the methoxyl carbons signals were observed at $\delta_{\mathrm{C}} 55.7$ and $\delta_{\mathrm{C}} 60.5$. The locations of the two prenyl moieties were located at the C-2 $\left(\delta_{\mathrm{C}} 110.9\right)$ and $\mathrm{C}-8\left(\delta_{\mathrm{C}} 137.3\right)$. In the COSY spectrum the nature of the allylic and homoallylic coupling systems within the isoprene unit was clearly demonstrated. It showed correlation between the olefinic proton of C-12 and benzylic proton of $\mathrm{C}-11$, and the germinal dimethyl group of $\mathrm{C}-14$ and $\mathrm{C}-15$. The same correlations above were also 
observed for the other prenyl moiety.

\section{Physical properties of $\mathrm{Cu}(\mathrm{II})$ complexes}

Metal complexes involving $\beta$-mangostin and copper metal produced green complex which was stable at room temperature. The ligand, $\beta$-mangostin (L) on interaction with copper(II) acetate yields complex corresponding to the general formula $\left[\mathrm{ML}_{2}\left(\mathrm{H}_{2} \mathrm{O}\right)_{2}\right]$. The analytical data showed that the metal to ligand ratio is $1: 2$. (Yield $72 \%$ ) Analytical calculation for $\mathrm{CuL}_{2}\left(\mathrm{H}_{2} \mathrm{O}\right)_{2}\left(\mathrm{MW}=946 \mathrm{gmol}^{-1}\right): \mathrm{C}=62.6 \%, \mathrm{H}=5.4 \%$. Found: $\mathrm{C}=63.4 \%, \mathrm{H}=6.1 \%$.

\section{Spectroscopic study of $\mathrm{Cu}$ (II) complexes}

IR spectra of $\beta$-mangostin has shifted in $\mathrm{v}(\mathrm{C}=\mathrm{O})$ peak from $1648 \mathrm{~cm}^{-1}$ to $1615 \mathrm{~cm}^{-1}$ and the $\Delta v$ (ligand - complex) is 33 [7, 8]. These absorption frequencies demonstrated that the group has lost its original characteristics and formed a coordinative bond with $\mathrm{Cu}$ (II) ion. Thus, this shows that the electron density in the carbonyl is slightly decreased probably due to back bonding process. Free $\mathrm{OH}$ stretching at $3399 \mathrm{~cm}^{-1}$ was absent and replaced with a broad $\mathrm{v}(\mathrm{OH})$ which was observed at $3438 \mathrm{~cm}^{-1}$ indicating coordination of water with $\beta$-mangostin. These data suggested that the oxygen of the carbonyl and hydroxyl have formed a coordination bond with the $\mathrm{Cu}^{2+}$ cation.

Another significant difference between the ligand and its metal complex was observed from UV spectrum. The UV spectrum of copper(II) complex shows a broad band at $22000 \mathrm{~cm}^{-1}\left(\lambda_{\max }, 450 \mathrm{~nm}\right)$ which presumably corresponded to $d$ - $d$ transition with octahedral arrangement [18]. The chelation of $\mathrm{Cu}(\mathrm{II})-\beta$-mangostin complex with bidentate ligand occurred with hydroxyl and carbonyl group at $\mathrm{C}_{9}$ and $\mathrm{C}_{1}$ respectively. The proposed structure of the complex was shown in Figure 2. The chelation formation in this study was similar to Farhan [19] and Wang et al. [7].<smiles>COc1cc2c(c(OC)c1CC=C(C)C)C(OC)c1c(cc(O)c(OC)c1CC=C(C)C)Oc1cc(O)c(CC=C(C)C)c(CC=C(C)C)c1C2OC</smiles>

Figure 2. The proposed structure of $\mathrm{Cu}(\mathrm{II})-\beta$-mangostin

\section{Antimicrobial properties}

$\beta$-mangostin was classify as inactive against the five bacteria tested. This antimicrobial result of $\beta$-mangostin was similar to Angia et al. [9]. Whereas the copper(II) complex showed weak inhibition with MIC value of $900 \mu \mathrm{g} / \mathrm{ml}$ to Pseudomonas aeruginosa, Proteus vulgaris, Klebsiella pneumonia and Salmonella pneumoniae but moderate inhibition with MIC value of $450 \mu \mathrm{g} / \mathrm{ml}$ towards Escherichia coli. The MIC value for positive control, streptomycin sulphate is $7.03 \mu \mathrm{g} / \mathrm{ml}$ for all bacteria used.

\section{Conclusion}

Copper(II)- $\beta$-mangostin complex, $\left[\mathrm{CuL}_{2}\left(\mathrm{H}_{2} \mathrm{O}\right)_{2}\right]$ was successfully synthesized with an octahedral geometry. The copper(II) complex showed more potent antimicrobial activity compared to ligand itself. This finding could lead to the development of new metal based bioactive compounds with enhanced antimicrobial properties, suitable for medical application and cosmetic products.

\section{Acknowledgment}

Authors are highly thankful to the Faculty of Applied Sciences, Universiti Teknologi MARA, Campus Samarahan 2, Sarawak and Ministry of Higher Education for given Fundamental Research Grant Scheme (FRGS) grant (FRGS/1/2014/ST01/UiTM/02/3) to support this study. 


\section{References}

1. Grazul, M., and Budzisc, E. (2009). Biological activity of metal ions complexes of chromones, coumarines and flavones. Coordination Chemistry Review, 253: 2588 - 2598.

2. Panhwar, Q.K., Memon S. and Bhanger, M.I. (2010). Synthesis, characterisation, spectroscopic and antioxidant studies of Cu(II)-morin Complex. Journal of Molecular Structure, 967: 47 - 53.

3. Aisha, A. F. A., Abu-Salah, K. M., Ismail, Z. and Abdul Majid, A. M. S. (2013). Determination of total xanthones in Garcinia mangostana fruit rind extracts by ultraviolet (UV) spectrophotometry. Journal of Medicinal Plant Research, 7(1): 29 - 35.

4. Yoshwathana, N. and Estiaghi, M. N. (2015). Optimization of subcritical ethanol extraction for xanthone from mangosteen pericarp. International Journal of Chemical Engineering and Application, 6(2): 115 - 119.

5. Sylvain V. T. Sob, H. K., Wabo, A. T., Tchinda, P., Tane, B. T. and Ngadjui, Y. Y. (2010). Anthraquinones, sterols, triterpenoids and xanthones from Cassia obtusifolia. Biochemical Systematics and Ecology, 38: $342-$ 345 .

6. Shagutfa, and Ahmad, I. (2016). Recent insight into the biological activities of synthetic xanthone derivatives, European Journal of Medicinal Chemistry, 116: 267 - 280.

7. Shen, R., Wang, P. and Tang, N. (2009). Synthesis, crystal structure, DNA-binding properties and cytotoxic activity of the copper(II) complex involving xanthone. Journal of Fluorescence, 19: $1073-1082$.

8. Wang, H.F., Shen, R. and Tang, N. (2009). Synthesis and characterization of the $\mathrm{Zn}(\mathrm{II})$ and Cu(II) piperidinyl isoeuxanthone complexes: DNA-binding and cytotoxic activity. European Journal of Medicinal Chemistry, 44: $4509-4515$.

9. Angia, V., Bakhtiar, A. and Arbain, D. (2015). The isolation of xanthones from trunk latex of Garcinia mangostana Linn. and their antimicrobial activities. Indonesian Journal Chemistry, 15(2): 187 - 193.

10. Fei, X., Jo, M, Lee, B., Han, S.B., Lee, K., Jung, J.K., Seo, S.Y. and Kwak, Y.S. (2014). Synthesis of xanthone derivatives based on $\alpha$-mangostin and their biological evaluation for anticancer agents. Bioorganic \& Medicinal Chemistry Letters, 21: 2062 - 2065.

11. Bukhari, S. B., Memon, S., Tahir, M. M. and Bhanger M. I. (2009). Synthesis, charaterisation and antioxidant activity copper-quercetin complex. Spectrochimica Acta, 71: $1901-1906$.

12. Destandau, E., Toribio, A., Lafosse, M., Pecher, V., Lamy, C. and Andre, P. (2009). Centrifugal partition chromatography directly interfaced with mass spectrometry for the fast screening and fractionation of major xanthones in Garcinia mangostana. Journal of Chromatography A, 1216: 1390 - 1394.

13. Ee, G. C. L., Daud, S., Taufiq Yap, Y. H., Ismail, N. H. and Rahmani, M. (2006). Xanthones from Garcinia mangostana (Guttiferae). Natural Product Research, 20: 1067 - 1073.

14. Gopalakrishnan, G., Banumathi, B. and Suresh, G. (1997). Evaluation of the antifungal activity of natural xantones from Garcinia mangostana and their synthetic derivatives. Journal Natural Product, 60: 519 - 524.

15. Sen, A. K. Sarkar, K. K., Mazumder, P. C., Banerji, N., Uusvuori, R. and Hase, T. A. (1982). The structure of garcinones A, B and C: Three new xanthones from Garcinia mangostana. Phytochemistry, 21:1747 - 1750.

16. Al-Massarani, S. M., El Gamal, A. A., Al-Musayeib, N. M., Mothana, R. A., Basudan, O. A., Al-Rehaily, A. J., Farag, M., Assaf, M. H., El Tahir, K. and Maes, L. (2013). Phytochemical, antimicrobial and antiprotozoal evaluation of Garcinia mangostana pericarp and $\alpha$-mangostin, Its major xanthone derivative. Molecules, 18: $10599-10608$.

17. Syam, S., Bustaman, A. Abdullah, R., Sukari, M. A, Hashim, N. M., Yahayu, M., Hassandarvish, P. and Abselwaheb, S. I. (2014). Cytotoxic and oral acute toxicity studies of $\beta$-mangostin isolated from Cratoxylum arborescens. Phcog Journal, 6: 47 - 56.

18. Yousef, T. A., Abu El-Raesh, G. M, Al-jahdali, M. and El-Rakhawy, E. R. (2014). Synthesis, spectral characterization and biological evaluation of $\mathrm{Mn}(\mathrm{II}), \mathrm{Co}(\mathrm{II}), \mathrm{Ni}(\mathrm{II}), \mathrm{Cu}(\mathrm{II}), \mathrm{Zn}(\mathrm{II})$ and $\mathrm{Cd}(\mathrm{II})$ complexes with thiosemicarbazone ending by pyrazole and pyridyl rings. Spectrochimica Acta Part A: Molecular and Biomolecular Spectroscopy, 129: 163 - 172.

19. Farhan, S. A. (2013). Study on the interaction of copper(II) complex of morin and its antimicrobial effect. International Journal Chemistry of Sciences, 11(3): 1248 - 1255. 